\title{
Tożsamość uniwersytetu w epoce niepewności
}

\begin{abstract}
Abstrakt
Tekst zawiera analizę rekonstrukcji społecznych funkcji współczesnego uniwersytetu, przy czym jako oś narracji przyjęto kategorię niepewności. Przedstawiono szereg kontekstów tworzenia trajektorii niepewności dezintegrujących zarówno tożsamość poszczególnych profesorów, jak i uniwersytetu jako instytucji. I tak omówiono między innymi wytwarzanie nowych form rywalizacji zarówno między jednostkami, dyscyplinami naukowymi, jak i placówkami edukacji wyższej. Zaprezentowano strategie wskaźnikowania, które redukują tożsamość i działania akademików do punktów, strategię nieustannego sprawozdawania, jak również swoistą makdonaldyzację dydaktycznej i naukowej funkcji uniwersytetu. Na zakończenie postawiono pytanie odnoszące się do możliwych sposobów działania uniwersytetu i profesorów w epoce niepewności.
\end{abstract}

Słowa kluczowe: uniwersytet, niepewność, rywalizacja, wskaźnikowanie, tożsamość.

\section{University identity in the age of uncertainty}

\begin{abstract}
The article includes an analysis of the reconstruction of social functions of contemporary university with the category of uncertainty assumed as the axis of narration. A number of contexts were presented of creating a trajectory of uncertainty disintegrating both the identity of individual professors and the university as an institution. They include, inter alia, the creation of new forms of competition between individuals, scientific disciplines, and higher education institutions, as well as strategies of assessment which reduce the identity and activity of academics to points, strategies of permanent reporting and specific mcdonaldization of the didactic and research functions of a university. At the end, a question was posed regarding the possible ways of acting of the university and professors in the age of uncertainty.
\end{abstract}

Keywords: university, uncertainty, competition, assessment, identity.

\footnotetext{
* Uniwersytet im. Adama Mickiewicza w Poznaniu.
} 
Zawsze chciałem pisać optymistyczne książki i wygłaszać optymistyczne referaty. Zawsze starałem się poszukiwać optymistycznych czy pozytywnych kontekstów - w rzeczywistości i w ludziach. Jednakże analiza warunków funkcjonowania współczesnego uniwersytetu nie pozwala na optymizm. Jesteśmy bowiem uczestnikami radykalnej i gwałtownej restrukturalizacji sfery akademickiej: tożsamości uniwersytetu jako instytucji, tożsamości zbiorowej akademików i ich tożsamości indywidualnej. Wykorzystując słowa Altbacha, można stwierdzić, że złoty wiek naszej profesji czy złoty wiek profesoriatu związany z dużym poczuciem kontroli nad swoją sytuacją zawodową minął bezpowrotnie (Altbach 1997: 315). Tracimy też poczucie elitarności naszej zawodowej tożsamości.

Bardzo lubię kategorię krystalizacji; wykorzystywałem ją w wielu moich książkach. Proces myślenia jest następujący: wybiera się kategorię, która krystalizuje w sobie interesujące badacza tendencje, zjawiska i procesy. Tworzy ona pryzmaty analityczne; stanowi swoistą „przeglądarkę”. Pozwala na wielokontekstowe rozważania, na tworzenie różnorodnych, także i sprzecznych ze sobą obrazów analizowanego problemu. W przeszłości takimi krystalizującymi kategoriami były dla mnie na przykład: kultura instant, globalny nastolatek czy all inclusive (Melosik 2001, 2007, 2014). Dla potrzeb dzisiejszego tekstu jako taką kategorię przyjąłem niepewność, która znakomicie - jak jestem o tym przekonany - oddaje klimat zmian w zakresie naszej akademickiej tożsamości.

Główna moja teza jest następująca: w ostatniej dekadzie mamy do czynienia z produkowaniem czy wytwarzaniem różnych form niepewności, które dezintegrują naszą tradycyjną tożsamość akademicką, wprowadzając i następnie pogłębiając poczucie braku kontroli nad kolejnymi sferami naszej sytuacji zawodowej. A poczucie niepewności sprawia, iż jesteśmy niespokojni, nie mamy dobrego nastroju, martwimy się i zamiast pisać książki debatujemy nad strategiami działania w warunkach niepewności, co zwrotnie pogłębia nasze poczucie niepewności. Pytanie: co z nami będzie? czy: jak ja się w tym odnajdę? - nabierają w naszych dyskusjach charakteru wręcz egzystencjalnego. Niepewność staje się swoistym moderatorem w naszych relacjach z naszym życiem zawodowym.

Mamy obecnie także do czynienia z - pogłębiającą nasze poczucie niepewności - produkowaniem różnych form rywalizacji między uniwersytetami, dyscyplinami i jednostkami. Rywalizacja staje jedną z podstawowych form naszej akademickiej egzystencji, wypierając współpracę i erodując przyjaźnie, różnicując i wartościując. Rywalizacja, w oparciu o starannie dobrane, często wręcz wyreżyserowane wskaźniki, tworzy nieustannie w kolejnych, opartych o zmienne kryteria - parametryzacyjnych czy algorytmicznych i zawsze statystycznych - odsłonach kolejne wersje zwycięzców i przegranych. To pogłębia nasze poczucie braku bezpieczeństwa. Nie koncentrujemy się na spokojnym uprawianiu nauki, lecz na nieustannym wypracowywaniu instytucjonalnych czy indywidualnych sposobów adaptacji do coraz to nowych i nowszych wymagań i reguł gry. W kulturze niepewności nie można jednak wypracować logicznych, spójnych i długoterminowych strategii adaptacji, 
bowiem zmiana jest szybka, wielokierunkowa i niedookreślona, jest niepewna. W kulturze niepewności nie bardzo wiadomo, do czego się adaptować. Musimy raczej pozostawać w nieustannej gotowości do adaptacji, do restrukturalizacji sposobów akademickiego i osobistego myślenia oraz naszej instytucjonalnej uniwersyteckiej działalności. Mamy, mówiąc banalnie, „gonić” z naszym akademickim życiem i naszymi uniwersyteckimi statutami za narzuconą z góry zmianą.

Najważniejsze działanie, w obliczu poczucia niepewności, niepewność redukujące polega na racjonalnym planowaniu przyszłości. Jak jednak konstruować i wprowadzać w życie taki plan, skoro - raz jeszcze podkreślę - funkcjonujemy w warunkach społeczno-ekonomicznej i formalno-prawnej niepewności i niestabilności - w znaczeniu zewnętrznie narzuconych zwrotów akcji i presji oraz zmiany warunków gry w czasie gry (często łącznie ze zmianą kryteriów dotyczących przeszłości)? W takiej sytuacji niepewność staje się formą sprawowania władzy nad instytucjami i jednostkami. A wszystkie badania naukowe wykazują, że to właśnie poczucie kontroli nad swoją sytuacją zawodową zwiększa zarówno poczucie satysfakcji z pracy, jak również jej efektywność i identyfikację z naszą instytucją oraz ze społecznością, której jesteśmy członkami. Zauważmy przy tym, że nieustanne zmiany różnorodnych sposobów i kryteriów oceny czy algorytmów lub trajektorii awansów naukowych powodują dezintegracje karier oraz biografii, aspiracji i motywacji jednostek, jak również uniemożliwiają uniwersytetom wypracowanie długofalowych strategii rozwojowych. To, co jeszcze niedawno wydawało się logiczne, dzisiaj wydaje się być mało ważne lub nawet pozbawione sensu.

Uczestnictwo w przymusowych, narzuconych - pod egidą walki o doskonałość akademicką - odgórnie formach rywalizacji wzmaga więc poczucie niepewności. W rywalizacji między uniwersytetami o miejsce w różnego typu rankingach my jako jednostki zostajemy zredukowani do malutkich bitów informacji w zbiorczych tabelach. Nasze zainteresowania i pasje, których rezultatem są pisane niekiedy przez lata artykuły i książki są zredukowane do różnego typu cyferek, obrazowanych przez jedną dziesiątą punkcika w jakiejś tabelce, która staje się częścią większej tabelki zbiorczej, a ta wielkiej makrotabeli. Tracimy naszą podmiotowość, a nawet jednostkowość. Procedury wskaźnikowania, które stały się integralną częścią naszej akademickiej rzeczywistości, nie mają charakteru jedynie diagnostycznego, ale także monitorująco-kontrolujący. Wskaźnikowanie stanowi formę sprawowania władzy zarówno nad uniwersytetami, jak i pracującymi w nich poszczególnymi akademikami. Jest przesycone władzą klasyfikowania i kategoryzowania instytucji i osób w zredukowane do statystycznych schematów segmenty. Przestajemy być członkami społeczności akademickiej, stajemy się członkami „społeczności statystycznej”. Musimy podporządkować się restryktywnym konsekwencjom analizy wskaźników po to, aby nasz wkład do następnego wskaźnikowania był większy (Melosik 2014: 389-400, por. też: Espeland, Stevens 2008). Wyniki wskaźnikowania, pogłębiając poczucie niepewności, służą - w celu uprawomocnienia różnorodnych reform - konstruowaniu kategorii kryzysu uniwersytetu. Katego- 
ria kryzysu staje się formą kryzysu inżynierii społecznej. Można zadać pytanie: czy kryzys rzeczywiście polega na tym, że polskich uniwersytetów nie ma w pierwszej setce rankingów? Gdy odwrócimy perspektywę, możemy stwierdzić, że kryzys polega na tym, iż w dążeniu do krótkoterminowych punktowych rezultatów w celu zwiększenia konkurencyjności naszych uniwersytetów rankingach przestajemy pisać - wymagającego wielu lat pracy - książki?

Badania naukowe nie znoszą ani pośpiechu, ani presji. Rozwiązanie problemu badawczego, który narodził się w umyśle badacza, wymaga czasu - zwykle wielu lat, a nawet dekad. Odkrywanie nowej prawdy o świecie i skrystalizowanie jej w nową wiedzę stanowi proces i nie jest „nagłym aktem” (wyjątek „eureki” Archimedesa tylko potwierdza tę regułę). W trakcie tego procesu myśl naukowca czy to fizyka-eksperymentatora w laboratorium, czy historyka cierpliwie studiującego dawne rękopisy przekształca się i dojrzewa. Niekiedy powraca do odrzuconych już idei czy pomysłów, niekiedy mknie jak Porsche na autostradzie po to, aby stanąć nagle przed czerwonym znakiem zakazu, bo okazało się, że to nie ta droga. Aż w końcu naukowiec - w wyniku długotrwałych systematycznych dociekań podejmuje decyzję: czas opublikować wyniki badań. Ileż to kluczowych dla rozwoju współczesnej nauki i postępu cywilizacyjnego odkryć powstało po kilkudziesięciu latach wysiłków badawczych... biografie wielu laureatów nagród Nobla dowodzą tego niezbicie.

Badania naukowe nie znoszą pośpiechu, a jednak współcześni naukowcy zmuszeni są pracować w kulturze niepewności - w presji natychmiastowości, której istotą jest presja na „szybki wynik”. Jakość wyników ich badań jest redukowana do prestiżu czasopism, w jakich są publikowane, oraz do ilości cytowań. Z kolei jakość ich naukowej biografii jest redukowana do różnego typu indeksacji. Czują się wtłaczani w (coraz to odmienne) algorytmy; są nieustannie - aby po raz kolejny użyć tego słowa - „wskaźnikowani”. W konsekwencji idea stopniowego odkrywania wiedzy zastąpiona zostaje ideą produkowania wiedzy, a dawna idea Prawdy staje się już tylko idealistyczną mrzonką. Algorytmizowani i parametryzowani naukowcy $\mathrm{w}$ coraz przy tym większym stopniu rezygnują z badań podstawowych, orientując się na wytwarzanie wiedzy na zamówienie, ponieważ to na takie badania znacznie łatwiej uzyskać środki finansowe (a która korporacja jest zainteresowana codziennymi zwyczajami Słowian czy kolejnym wydaniem dzieł wszystkich Słowackiego?). Wiedza naukowa, uważana jeszcze niedawno za formę dziedzictwa kulturowego i źródło integracji społecznej, obecnie rozpatrywana jest coraz częściej w kontekście rynkowej wartości użytkowej. Dawne pytanie „czy to jest prawdziwe?” zastępowane jest przy tym przez pytanie „co ja z tym mogę zrobić w praktyce?” (Melosik 2009: 61-72, 73-81).

Pisać trzeba szybko i dużo, ponieważ zasada Publish or Perish („publikuj lub giń”) zaczyna dominować w naukowej kulturze wyższych uczelni. Naukowcy - jak już podkreślano - zmuszeni są przy tym funkcjonować w warunkach nieustannego współzawodnictwa z kolegami z tej samej uczelni, innych uczelni w kraju i na 
arenie międzynarodowej. W konsekwencji, dawnych Wielkich Mistrzów Nauki, potrafiących samodzielnie - z mocy władzy własnego umysłu - tworzyć teorie i dokonywać odkryć mających wpływ na rozwój cywilizacyjny zastąpiły często tworzone ad hoc grupy zorientowane na krótkoterminowe, poddające się komercjalizacji badania i szybkie publikacje. Unika się przy tym coraz częściej podejmowania „ryzykownych”, obciążonych możliwością niepowodzenia badań, a przecież - jak dowodzi tego historia nauki - to one często prowadziły do przełomów i genialnych odkryć. To właśnie taka strategia (unikania) przynosi większą szansę parametryzacyjnych sukcesów. Zanika idea „Szkół Naukowych” związanych z kontynuowanymi przez kolejne generacje, jasno wyróżniającymi się od innych, paradygmatycznymi sposobami myślenia. W naukach humanistycznych i społecznych - zgodnie z logiką parametryzacji - tracą znaczenie Wielkie Dzieła, przygotowywane zwykle przez kilka, a niekiedy przez kilkanaście lat monografie, które stanowią apogeum pasji i satysfakcji z pracy naukowej. A przecież to właśnie książka stanowi apogeum akademickości, poczucia satysfakcji i realizacji pasji, a także źródło prestiżu w - kreowanej przez wspólne intersubiektywne znaczenia - społeczności akademickiej. Jak stwierdziłem w jednym z moich wystąpień: Istotą naszej biografii - jako naukowców - jest odkrywanie tajemnicy wiedzy, jest dążenie do zrozumienia prawdy. Nie ma nic piękniejszego niż ta - powodująca skok adrenaliny - eureka, gdy kiedyś gęsim piórem, potem pracowicie długopisem, potem na maszynie do pisania, a dziś zwykle na komputerze - składamy słowa, zdania układają się $\mathrm{w}$ akapity, te $\mathrm{w}$ rozdziały, $\mathrm{w}$ książkę. Na tym polega sens naszej pracy, niekiedy sens naszego życia.

W obliczu nieustannego podważania zmiany sposobu funkcjonowania uniwersytetów w odniesieniu do Wielkiej Brytanii pisze się wręcz, że uniwersytety zostały tam zmacdonaldyzowane. Przywołując poglądy Hayesa i Wynyarda (2016: 79), można stwierdzić, że „McUniversity został zdominowany przez McMenedżerów”, których rola gwałtowanie wzrasta. McNaukowcy przeprowadzają na zamówienie McBadania i produkują szybkie McArtykuły. McWykładowcy nie mają nic wspólnego z klasycznymi profesorami i nie koncentrują się na słowie, lecz na technologii przekazu. McStudenci zbierają punkty ETCS i piszą McEseje (tamże). Na brytyjskich uniwersytetach akademicy są przy tym nieustannie „regulowani” przez władzę, która nieustannie zmienia reguły gry w oparciu o narzucone kryteria, których nie akceptują.

Konkurujące ze sobą amerykańskie i brytyjskie uniwersytety zarządzane są w coraz większym stopniu w sposób menedżerski. Odwołując się do rozważań Gumport (2000: 72-73, 76), można stwierdzić, że coraz mniejszą rolę odrywają profesorowie - intelektualiści, coraz większą typowi menedżerowie, którzy - nie mając z nauką i nauczaniem nic wspólnego - wyznaczają jednak tym pierwszym cele i zadania, rozważają „aktywa” i „pasywa”, przewidują „koszty” i „korzyści”, zwiększają efektywność. Akademicy są postrzegani przez menedżerów w katego- 
riach „kalkulatywnych” (jako mniej lub bardziej wydajni pracownicy): uważa się, że można ich w odpowiedni sposób „motywować” poprzez bodźce i sankcje (tamże).

W konsekwencji, w kontekście funkcji dydaktycznej uniwersytetu profesor przestaje być „mistrzem”, zostaje zredukowany do „tutora” czy wręcz prostego „przekaźnika” (pasa transmisyjnego) pożądanej wiedzy i kompetencji. Profesor, jak przekonująco twierdzi Winter (1995), traci kontrolę nad celami, sposobami i ewaluacją kształcenia - wszystko to staje się domeną pracodawcy i ogólnouniwersyteckich oraz zewnętrznych „procedur jakości kształcenia”. Kontakt akademików ze studentem jest coraz bardziej fragmentaryczny, są już oni jedynie „dostarczycielami towaru w ramach «supermarketu wiedzy», który może, ale nie musi być wybrany przez studenta-klienta". Zgodnie z logiką rynku relacje między nauczycielem, studentem i programem nauczania są rekonstruowane w relacje między producentem, konsumentem i towarem. Po pierwsze wiedza jest zapakowana w gotowe i łatwe do przyswojenia „paczki” czy „pigułki”. Po drugie edukacja wyższa upowszechnia głównie taką wiedzę i kompetencje, które posiadają wartość rynkową i dzięki temu mogą stać się dla studenta „kredencjałem”. Uniwersytet więc „sprzedaje” rynkowi grupy absolwentów, którzy zredukowani są do posiadanych przez siebie kwalifikacji (Winter 1995: 133-136).

W warunkach kultury niepewności naukowcy tracą kontrolę nad swoimi biografiami naukowymi, muszą być maksymalnie reaktywni wobec zewnętrznie narzuconych odpowiedzi na podstawowe pytania: jakie kryteria definiują wartościową wiedzę?; co to znaczy być dobrym naukowcem? Podobne uwagi podnieść można w stosunku do uniwersytetów jako instytucji. Poddanie ich presji uczestnictwa w warunkach - powtórzę raz jeszcze - nieustannej konkurencji o środki przyznawane w oparciu o kryteria zmieniane z każdą kolejną parametryzacją powoduje kwestionowanie ich tradycyjnej tożsamości, związane z funkcjonowaniem w roli „Świątyni Mądrości”, następuje ich radykalna desakralizacja. Przekształcane stopniowo w przedsiębiorstwa rekonstruują swoje działania i cele, zmierzając do polepszenia swojego miejsca zarówno w polskich, jak i międzynarodowych rankingach. Te drugie stanowią - jak twierdzą krytycy - formę narzucania całemu światu jako „idealnego” tego modelu instytucji szkolnictwa wyższego, jakim jest elitarny badawczy uniwersytet amerykański (typu Stanford) (por. Gromkowska-Melosik 2015: 9-10). W międzynarodowych rankingach skomplikowana, pełna lokalnych tradycji i narodowej lub wręcz lokalnej kultury uniwersytecka rzeczywistość różnych krajów jest redukowana do ilościowych wskaźników, postrzeganych przy tym jako uniwersalne i obiektywne. Dążenie do „skoku w rankingu” prowadzi do restrukturalizacji całego sposobu uprawiania nauki i myślenia o uniwersytecie. Pomija się jego kulturotwórczą rolę, a jakość czy poziom są - w coraz powszechniejszej percepcji - postrzegane przez pryzmat miejsca w rankingu. Sytuację komplikuje fakt, iż w najważniejszych z nich występują odmienne kryteria oceny, co ma wpływ na pozycje poszczególnych uniwersytetów. Widać to wyraźnie na przykładzie „Times Higher Education World University Rankings”, „QS University Ranking” oraz „Academic Ranking of World Universities” (tzw. Szanghajskim). 
W porównawczych analizach tych rankingów dostrzec można radykalne „przetasowania”. Niektóre uniwersytety w jednym rankingu znajdują się relatywnie wysoko, a w innych w ogóle ich nie ma. Następują także niekiedy zasadnicze zmiany w pozycji poszczególnych uniwersytetów z roku na rok (Gromkowska-Melosik 2015).

Trzeba dodać, że w reakcji na nieustanną presję na rzecz krótkoterminowych „szybkich badań” oraz pogłębiający się klimat rywalizacji i walkę o miejsce w rankingach, w międzynarodowych dyskusjach na temat uprawiania nauki coraz częściej pojawia się idea slow research lub slow science odwołująca się do tradycyjnych sposobów konstruowania biografii naukowych oraz tożsamości uniwersytetu, do nauki, która wychodzi poza dominującą zasadę natychmiastowości, poza niepewność.

Klimat niepewności i rywalizacji przynosi powstanie neurotycznej akademickiej tożsamości. W warunkach niepewności, w których funkcjonuje uniwersytet, każda ocena, czy to indywidualna czy instytucjonalna, nie jest ostateczna. Każda ewaluacja czy parametryzacja jest punktem wyjścia następnej gry, zwykle w cyklu czteroletnim lub krótszym. Każde uprawnienie można utracić, każda dotacja może być mniejsza już w przyszłym roku. Nasze akademickie życie, szczególnie osób pełniących ważne funkcje, staje się bardziej nerwowe niż w przeszłości. Staje się szybkie, w dużej mierze sytuacyjne, pozbawione możliwości planowania na dłuższą metę. Jakże aktualne są w tej materii rozważania Horney, która w książce Neurotyczna osobowość naszych czasów pisała: „konkurencyjny duch naszej kultury jest nie tylko pożywką dla nerwic w ogólności - poprzez wzbudzanie niepokoju w związkach między ludźmi - ale też w specyficzny sposób nasila potrzebę górowania” (Horney 2011: 104-105). Współczesnego człowieka, nie tylko w sferze akademickiej, cechuje też neurotyczna „potrzeba osiągania perfekcji” i „kompulsywne dążenia do sukcesów”, które „mogą się rozwijać tylko w kulturze rywalizacji”, a także „paniczny strach przed klęską” (Horney 1978: 30, 33, 39). Narzucone nam różnorodne formy konkurencyjności dezintegrują - jak już pisano - akademickie społeczności, wprowadzają klimat nieufności, a często zawiści i - jak to ujmują Elliot, Katagiri, Sawai (2012: 440) - „kompulsywnego czytania atmosfery relacji interpersonalnych" (tamże). Tracimy spokój ducha. W podobny sposób ustosunkowują się do tej kwestii i inni amerykańscy autorzy, twierdząc, iż typowa dla współczesności hiperkonkurencyjność

odzwierciedla bezkrytyczną akceptowaną potrzebę współzawodnictwa i zwycięstwa (...), niezależnie od kosztów, co ma stanowić źródło utrzymania lub wzmocnienia poczucia własnej wartości i jest przede wszystkim związana z osiągnięciem osobistej przewagi (...) [i] pomniejszaniem znaczenia innych (Thornton, Lovley, Ryckman, Gold 2009: 266).

Kolejny kontekst poczucia niepewności tworzy zamknięcie nas w gorsecie - wszechogarniających nasze życie akademickie - zwielokratniających się formularzy, procedur, sprawozdań, raportów i kwestionariuszy. Zarówno instytucja aka- 
demicka, jak i poszczególny akademik zdaje się stawać dodatkiem do nich. Działamy od procedury do procedury poprzez procedurę, niekiedy mam wrażenie, że jesteśmy tylko przypisem do wielostronicowych instrukcji dotyczących udokumentowania naszego akademickiego istnienia. Jesteśmy coraz bardziej zamknięci w schematach i ograniczeniach pożerającej nasz czas i nasz umysł biurokracji. A przy tym błędne wypełnienie obowiązujących, patrzących na nas podejrzliwym okiem rubryczek przynosi często bardzo negatywne konsekwencje i sankcje (Melosik 2014: 333-362).

Jakie działania można podejmować w warunkach kultury niepewności? Odpowiedź na to pytanie jest niezwykle trudna. I nie podejmuję się dać jakiejkolwiek jednoznacznej odpowiedzi. Na poziomie instytucjonalnym zależy to od liderów, rektorów czy dziekanów, na poziomie indywidualnym - od charakteru i motywów poszczególnych jednostek. Bez wątpienia jednak istnieje konieczność konsolidacji polskiej pedagogiki akademickiej w walce o status naszej dyscypliny w ramach nauk społecznych i humanistycznych, a także w szerszym kontekście społecznym. Istnieje konieczność podejmowania nieustannej refleksji nad naszą tożsamością akademicką - zarówno instytucjonalną, jak i jednostkową. I przede wszystkim, aby wprowadzić nieco optymizmu, istnieje konieczność, aby w warunkach niepewności zachować daleko idącą pewność siebie.

\section{Bibliografia}

Altbach P. G. (1997) The International Academic Crisis? The American Professoriate in Comparative Perspective, „Daedalus”, 16/4: 315-338.

Elliot A., Katagiri M., Sawai A. (2012) The New Individualism and Contemporary Japan: Theoretical Avenues and the Japanese New Individualist Path, "Journal for the Theory of Social Behaviour", 42/4: 425-443.

Espeland W. N., Mitchell L. Stevens (2008) A Sociology of Quantification, "Archives of European Sociology" (AES), XLIX (3): 401-436.

Gromkowska-Melosik A. (2015) Globalne rankingi uniwersytetów i akademicka gra o status, „Studia Edukacyjne”, 37, s. 7-21.

Gumport P. J. (2000) Academic restructuring: Organizational change and institutional imperatives, „Higher Education”, 39: 67-91.

Hayes D., Wynyard R. (2016) The McDonaldization of Higher Education Revisited w: Routledge Handbook of the Sociology of Education of Higher Education, (ed.) J. E. Cote, A. Furlong, Abingdon and New York.

Horney K. (1978) Nerwica a rozwój człowieka, Warszawa, PIW. 
Horney K. (2011) Nasze wewnętrzne konflikty. Konstruktywna teoria nerwic, Poznań, Rebis.

Melosik Z. (2001) Młodzież i styl życia: paradoksy pop-tożsamości w: Młodzież, styl życia i zdrowie. Konteksty i kontrowersje, red. Z. Melosik, Wydawnictwo Edytor.

Melosik Z. (2007) Teoria i praktyka edukacji wielokulturowej, Kraków, Oficyna Wydawnicza „Impuls”.

Melosik Z. (2009) Uniwersytet społeczeństwo. Dyskursy wolności, wiedzy i władzy, Kraków, Oficyna Wydawnicza „Impuls”.

Melosik Z. (2014) Kultura popularna i tożsamość młodzieży. W niewoli władzy i wolności, Kraków, Oficyna Wydawnicza „Impuls”.

Thornton B., Lovley A., Ryckman R. M., Gold J. A., (2009) Playing Dumb and Knowing it all. Competitive Orientation and Impression Management Strategies, "Individual Differences Research", December, 7 (4).

Winter R. (1995) The University of Life plc: the „Industrialization” of Higher Education? w: Academic Work, (ed.) J. Smyth, Buckingham. 